\title{
Developing the ways of managing the financial market functions in the railway transportation of Kazakhstan during the crisis
}

\author{
Nursulu Alashbayeva ${ }^{1, *}$ \\ ${ }^{1}$ Kazakh University of Economics Finance and international trade. Str., 11, 010000 Nur-Sultan, \\ Kazakhstan
}

\begin{abstract}
The stability of economic relations is the basis of intensive development of an each country. Variation of economic factors in the globalization process of the market economy is very important in maintaining the competitiveness of the Republic of Kazakhstan (RoK) in the world system of market relations. The globalization of the market economy and growing competitiveness directly affect the economic stability of the country. The dynamics of the financial market makes contributions not only in micro level but also in macro level. Accumulation of financial resources in selected market and the balance between fluctuating economic factors that affect them are proof for functioning of the financial market. In addition, we are discussing here about institutional changes, changes in the normative and legal acts, also about governmental support for reform processes which affect to the management of railway transportation. The paper determines the funding problems in passenger transportation requires the direct participation of the government.
\end{abstract}

\section{Introduction}

The relevance of the theme. In any financial market, during economic factors' fluctuation, financial institutes that regulate cash flow from property owners to borrowers play a key role. Payment instruments and securities are applied as goods. A set of financial and business relations directed to establish a direct link between sellers and buyers of financial resources is called financial market. The financial market has an important role in economic development, because there performed many social and economic processes, capital investment and mobilization of population funds. And this is a prerequisite for the functioning of the stock market. The Address of the President Nursultan Nazarbayev "Kazakhstan in the new world" determined the main development factors of the Kazakhstan's current state, external and internal policy of the country and noted the establishment of a effective stock market as a basis for the development of the financial system. Through the stock market free money of population can be invested in securities. There is needed a

* Corresponding author: Shynar.turarova@gmail.com 
mechanism that will control the effective operation of financial and stock market at the state level, ensuring the balance of economic factors.

That's why the strategic development of the stock market is pointed out as an important market modernization in the "Strategy of Industrial and Innovation Development of Kazakhstan for 2003-2015" [1]. In order to solve this problem we need to develop the internal institutional investors and the multi-level control system, in addition we need to ensure the efficient functioning of the technical infrastructure of the stock market. It is important to increase the number of high qualified specialists among financial intermediaries in attracting free money of population to the Kazakhstan's stock market [2]. The lack of confidence among people and enterprises' managers on the stock market dissuade them to buy and sell their shares on the open market, as well as increases their doubts about the source of additional investment. Frequent changes of current economic factors make Kazakhstan to adopt a longterm investment strategy for the development of the stock market. To propose strategy scripts with the help of fundamental research shows the relevance of the research.

\section{Brief Literature Review}

With anti-crisis management of transport and rail transport, one can see the work of many foreign, domestic authors. The world crisis has shown that domestic resources are the most important and reliable for the development of the national economy.

According to experts' assessment the volume of domestic financial resources that has been not been attracted to the country's economy compose $12 \%$ of GDP. Here we are talking about the funds of population and enterprises because most of them prefer to work with foreign banks instead of Kazakhstan. Therefore, attracting domestic funding source (mobilization) is an important task. In this aspect, we should stop to accumulate external sources, means of the bank's pension fund and insurance companies, into internal. In addition, the mechanism for development of the stock market and for attracting finance into the economy needs to be improved. [3], N. M. Alashbaieva [4, 5, 6, 12, 13], Faroukh Nourzad [7], Devereux M., Smith G [8], Obstfeld M. [9], Kaliev E.Zh. [11], Keister A. L. [15] .

\section{Materials and methods}

Financial market is a private economic factor that implementing the sale and re-sale transactions of securities by implementing a set of market relations helping to attract free funds of enterprises, firms, banks, pension funds, insurance institutions, a state and population. It is an integral part of the system of market relations and closely connected with the commodity, money, credit, insurance, currency and other markets (capital, work force, housing, land, gold and other markets). Finance plays a crucial role in the structure of market relations and in the mechanism regulating them by the state.

Objectives of a sociological study:

- to develop ways to manage the functions of the financial market in railway transport;

- anti-crisis risk management of the railway industry of Kazakhstan.

Despite financial difficulties, the life of Kazakhstan citizens is improving day by day. If GDP per number of people was \$ 700 in 1994, then in 2011 it exceeded \$ 6,000, increased by 10 times. In 2020 Kazakhstan's GDP should reach 10 thousand dollars to join till 2024 the countries with a high level of income. [4]. Global financial markets have to pay attention to the economies of many countries in order to find an answer to the important question.

\section{Results and discussion Discussion}


It is impossible to conduct a research by a common indicator taking into account the specific features of the different segments. For example, it is impossible to compare the indicators of a money market and a capital market with the market of insurance services. However, it is possible to compare the basic tools. Mostly appendices of the Annual report of the International Monetary Fund contain the amount of the bank's assets, issued debt papers and show market price of shares traded on the stock exchanges.

Table 1. Main economic indicators of the Republic of Kazakhstan and the world leading countries during 2016-2018, \%.

\begin{tabular}{|l|l|l|l|}
\hline GDP & 2016 & 2017 & 2018 \\
\hline USA & $-2,6$ & 1,6 & 2,5 \\
\hline European Union & $-2,7$ & 0,5 & 1,4 \\
\hline Japan & $-4,3$ & 0,8 & 1,5 \\
\hline Kazakhstan & 1,2 & 7,3 & 7,5 \\
\hline Inflation & & & \\
\hline USA & $-0,7$ & 1,6 & 1,4 \\
\hline European Union & 0,6 & 1,3 & 1,5 \\
\hline Japan & $-0,6$ & $-0,1$ & 0,6 \\
\hline Kazakhstan & 7 & 7,2 & 7,5 \\
\hline Unemployment & & & \\
\hline USA & 8,8 & 9,4 & 9,8 \\
\hline European Union & 8,9 & 9,9 & 11,5 \\
\hline Japan & 4,7 & 5 & 5,2 \\
\hline Kazakhstan & 6,6 & 6,8 & 5,4 \\
\hline $\begin{array}{l}\text { Refinancing performance of the } \\
\text { Central Bank }\end{array}$ & & \\
\hline USA & 0,18 & 2,13 \\
\hline European Union & 0,85 & 0,9 & 1,5 \\
\hline Japan & 0,08 & 0,46 & 1,2 \\
\hline Kazakhstan & 7 & 7 & 7,5 \\
\hline Note: The table was composed by author on the basis of the sources [6] and [7]
\end{tabular}

The issue about the state role in transition to a market economy is an actual question for Kazakhstan. It is still being a subject of discussion and evaluation, but as an important and mandatory component of the economic growth it requires to conduct an active policy.

It has passed a very long time since the establishment of the railway industry of the Republic of Kazakhstan and that was a sufficient period of time to replenish occurred and emerging defects, to assess its advantages and disadvantages.

It was a time to scientifically evaluate its effectiveness, to meditate on modern financial policy formulation and implementation, to determine development trends of the financial sector. It is a good way to see what position it holds, how it is being used in practice, what has it accept and has not accept. In general, it should be noted that our country could endure the challenges of the time during the transition period. Its fundamental rules have been approved in our country and in the present position it is capable to allocate sufficient financial resources for the protection of public relations from the financial crisis. No matter how much we have discussed the railway industry, its action, taking into account all the shortcomings, contributed to the formation of new political, social and economic relations. Although there are advantages of the rail industry, but it could not elude the shortcomings that is now being observed.

And that is quite a natural phenomenon: any financial policy of the state that can protect 
the global financial crisis is imperfect because the person himself is underdeveloped. Life does not stand still, that is why we have to keep track of its every change and solve emerging problems [8].

The scope of this article do not allow me to cover full material of the railway industry of Kazakhstan, therefore, I think I will talk only about some of the principles that needed to be improved further.

The economy of the Republic of Kazakhstan in the field of railway financial study of the theoretical and practical issues of state regulation of the industry is still a subject never been. Railway the formation of the state regulation of the economy, calls for the creation of a new market, taking into account the specifics of our state the need for a thorough investigation of these issues it requires. This all proves that is necessary to examine this problem before. Railway entered into a life of Kazakhstan for a long time. It is impossible to imagine the economy without state railway. For a million people the train became familiar and indispensable transport. With the help of the railway Kazakhstan's independence has become more intensified and strengthened.

$70 \%$ of the total cargo turnover and $60 \%$ of passenger transportation are accounted for the country's railway transportation. This fact provides the responsibility not only of the current work of the railway line, but also it requires seriously focus on its future. At the present stage there are should be carried out institutional changes, introduced a number of amendments to the normative-legal acts, as well as, the state should support the reform processes that affect the basics of railway transport management.

Solving the subsidising problems in passenger traffic and its social value requires the direct involvement of the state. The shortage problems of investment resources in the field of Kazakhstan railway is not going to be solved just with the effort of "Kazakhstan Temir Zholy National Company" JSC.

These investments are necessary to renew basic instruments, production facilities and staff, including major restorative repair, modernization of the new locomotives and wagons. Also investments are needed in building new roads with the participation of assembly plants.

Obviously, the policy that is being conducted to modernize the railway transport comprehensively will increase its role in the future. The efficiency of the industry will increase and it will develop in accordance with the twenty-first century. In the end, the railway will meet the growing requirements of the Kazakhstan's economy. The new opportunities will appear for implementing the unique transit potential of the country.

Domestic and foreign investors will be able to estimate the cost of their transferred financial investments to the industry [8]. The stable operation of the Kazakhstan's transportation, mainly the railway industry, is the primary condition for the functioning of the economy in the framework of the raw material program. Development of the industry allows improving the technical equipment of the Kazakhstan railway, in 2017 to bring closer to the world standards, to increase the competition by improving the transit potential, to increase the level of import substitution and to develop the transport infrastructure.

Reducing transport costs in manufacturing costs of the domestic production will affect the strengthening of economic growth and economic security of the state. The economic security problem of the state transportation system is essential for the safety of the country, so you need the full support of the state to solve it. It is required to develop the level of transportation that can withstand internal and external threats, satisfy the transportation needs of the population and any vital needs of the economy, and ready to work in extreme cases.

The migration process in the primary production of the railway so it clarifies the quantity and quality obligations in the technical field of "The railway of Kazakhstan" NC CJSC in the organization, later during this prescribed material and labor resources of its spending [9].

Taking into account the world experience effectiveness of using a simplifield operating expenses portable operation function is reduced to $7-10 \%$. The organization of transportation 
process provides the most efficient way to select and use the smallest for the intended use of cargo flows (organizing wagon flows, organization of train schedules, locomotive and locomotive crew's organization etc.).

Management of the traffic really should reduce change prepared charts. Operational plan infrastructure allows precise indication of stream and planned traffic. This enables the refinement of many roads, signaling and communications equipment list and still determines the development of infrastructure.

In the last decade, it has decreased the volume of traffic, so Kazakhstan has excess assets. The purpose of mapping and reducing unnecessary assets to keep them in order and protect from harmful things.

The change in volume, structure and direction of the main traffic have extra reserves. The main goal of simplifying the reserves necessary to plan the removal of unnecessary and fixes available. In other words, it is necessary to compare the profile using the technical side of the exemplary and the structure of the transport.

Analysis of the existing roads and the need to implement a long-term program to reduce the requirements. Asia Development Bank, according to experts of the European Bank for Reconstruction and Development, the length of the station and the special ways to reduce by $25 \%$ by the year 2016 . Basically station and access Lines as well as to reduce the length of the smaller networks. So high speed networks in order to reduce the capital costs required to restore the double-track double the sum of the individual sites suitable for the construction of the second line to reduce the length of the replacement. The ways allows you to get some top of the line materials according. The experts a considerable reduction of the locomotive park to continue the process started. To continue the process begun in 1997, the locomotives which expired will not be corrected and removed from the list.

Locomotive fleet until 2006 teamed up on 1473, it has decreased to $25 \%$ and further locomotive fleet referring to the planned update to 2014 decreased by $1200-1300$.

During this period, all the locomotives have been written off, removed from the list mainline locomotive fleet to 430 units to 500 units of electric locomotives, diesel locomotives to 300 units.

"The railway of Kazakhstan" NC CJSC carry the weight of the cars in the car park professional period of a 35\% flat cars available. In 1993-2000 years fleet write-down, the average annual growth rate of more than $3 \%$.

By 2015, to increase their work time making repairs and purchase of cars is planned to increase to one thousand units of the park.

In theirs open wagons will be heavy. Astana a lot of weight in the high-speed train service between Almaty and we are going to provide in the third quarter of 2004. In July 2003, 44 of new style of the "Talgo" coaches. These coaches recruited people.[10]

As for the main purpose of the investment program through to a qualitatively new level in the industry are: the major use of modern technology infrastructure rehabilitation; the construction of a new railway line; the full awareness of the industry, automated transportation management center, which $\mathrm{ADBO}$ modern process control the establishment of the center, the construction of the fiber-optic network;

Restoration and renovation of rolling stock and locomotive repair factory base car and the creation of new import-substituting industries; the domestic branch of science; the introduction of new resource-saving technologies in the production process.

Fixed assets in advance of the planned maintenance and repair work done on their system in order to transition to a modern diagnostic compositions used. In a programme the implementation of the planned projects to improve the technical and economic criteria in accordance with the requirements of modern rolling stock and infrastructure elements of the planned change by the accumulation of domestic fleet upgrade locomotives and wagons and to ensure the sustainable development of the industry. [11] 
Kazakhstani railways to bring the level of technical equipment in the world by 2015, and will be able to achieve a high level of competence. The investment program is typical of the majority of the CIS countries written technological independence from the center of the line of the Soviet Union, the development of alternative transit corridors, the moral degradation of the main tools for rail transport, technological backwardness of the previous achievements of science and technology for more than 90 years, due to a fall in the volume of traffic capacity, and the rolling stock is subject to a number of historical factors such as the size of the contingent.

On the other hand, the industry's growth is limited in the case of serious financial and economic management of resource-saving and high-technology industry a new system of flexible transition to a new economic model based on the need for a strategy describes investment. Which points economic growth strategy through consolidation of resources will require a radical restructuring of the investment process.

In recent years, the economic growth of the Republic of Kazakhstan achieved and the carrier providing service to attract private investment in the development of competition and the need for further restructuring of the railway transport railway line is one of the main principles of the restructuring. With this remain the property of the state of the economy of the Republic of Kazakhstan and to meet the needs of development in order to increase the transit potential. [12]

At the same time, the need for further restructuring of the national carrier of the main network operator and the allocation of financial backbone network carriers to ensure equal access to all of its activities in the rail transport of the Law of the Republic of Kazakhstan, as well as the competitive potential of the railway natural monopoly on the distribution services of natural monopolies in the transport. Railway causing road transport in accordance with the Law of the Republic of Kazakhstan, the government and society to achieve optimal system is the purpose of the restructuring.

The following tasks must be completed in order to achieve this goal: improvement of the regulatory framework for rail transport; to provide distribution services; the main carriers of the right to use the railway line to create a competitive market; optimization of production capacities, increase the efficiency of rail transport; subsidizing passenger traffic problems on the road. Railway National Railway Company in accordance with the Law of the Republic of Kazakhstan, the main operator of the network carriers to provide equal rights to the use of the main railway line [13].

The development of competition in the transport rolling stock was due to the emergence of new carriers.

In this case, the state under the railway transport policy: all railways in possession of various types and categories of the arrival of the railway system of regulation; the role of the railways in terms of its economic and social benefits of recognition; in comparison with the rates of other sectors (leading) iron to ensure the development of the road.

Reconstruction of the railway transport tariff and tax policies in the field of modernization of the country through the territory of the country and them to satisfy domestic consumption, it is necessary to pay attention to the development of new transport.

Transport to reduce traffic problems, to improve the quality and reliability of the railway system integration impossible, to solve problems in the field of economy.

Kazakhstan is not only different, which provides an opportunity to improve the overall economy of the country, in-depth study of the development of the railway sector in the medium-term program (investment).

The effectiveness of the implementation of the transit potential of the country in danger active policy to attract transit flows on the territory of neighboring states. If the railway transport would be viewed as a source of tax revenues, these facilities will be built, but also in neighboring countries. 
So, lose self-fund the development of railway transport, and the country's economic collapse. Marketing to ensure the competitiveness of rail transport on the basis of (a subsubsidiary) further developed. Section of private property on the basis of the enterprises, the volume of services provided by other organizations loops. The Kazakhstan railway line.[14]

Transport corridors of freight traffic, including transit cargo flows. Republic hold cargo and passenger transportation in the territory of one of the shortest route from point to point. Currently a new stage in the reform of the railway sector is being held, during which the internal and external market further development of competition in the market.

The formation of a single economic space in the framework of the expansion of the commodity markets and to increase competition in the last. The members of the Customs Union the formation of the Common Economic Space of goods, works and services open unhindered movement seems to be directly related to the railway line.

This stage of the reform of the railway industry in the countries of the Customs Union, the industry's current and target models, there is a difference of principle. The difference, in particular in the field of railway transport market positions of legislative [15]. Currently, physically worn-out condition of the railway assets, moral technology, and is characterized by competitive characteristic of the national carrier. So opportunity to compete with foreign companies to compete in foreign markets should provide for an appropriate level of rail infrastructure. Adapted to the requirements of modern railway transport, as a party to the equal competitive global market. For this be compatible with the traffic, taking into account the increase of international competition, public support for the railway industry of the Republic of Kazakhstan. So public support for the adoption of such measures this should be taken as the monopolization of industries. We must take into account the real situation in the country. Unlimited power and local official's capital is accumulated, the property could be divided: the raiding of legal entities (especially in the field of railway transport). These issues for the development of transport infrastructure and the development of competition in this segment developed solution within the framework of the program for the years 2012-2018.

Table 2. Transport infrastructure development program for 2012-2018.

\begin{tabular}{|l|l|}
\hline \multicolumn{1}{|c|}{ Strengths } & \multicolumn{1}{|c|}{ Weaknesses } \\
\hline $\begin{array}{l}\text { Is in the middle of the communication flow } \\
\text { between Europe and Asia transit-transport } \\
\text { potential of Kazakhstan; the reform of the } \\
\text { railway sector (domestic and foreign } \\
\text { competition in the market for further } \\
\text { development); all rail-term impact on the } \\
\text { provision of round-the-clock service. }\end{array}$ & $\begin{array}{l}\text { Competitiveness of the railway: physically worn-out } \\
\text { assets, moral technologies; "NC" KTZ "group of } \\
\text { companies of monopolistic stored in the rail } \\
\text { transport market share; Affiliation to the subjects of } \\
\text { the railway industry market; spare (service) to } \\
\text { restrict competition in the field; failure to equal } \\
\text { access to the infrastructure of the railway transport; } \\
\text { with the owners of enterprises of railway transport } \\
\text { and railway stations on the actions of the lack of } \\
\text { legal framework. }\end{array}$ \\
\hline $\begin{array}{l}|c| \\
\text { Features }\end{array}$ & \multicolumn{1}{|c|}{ Threats } \\
\hline $\begin{array}{l}\text { Within the framework of the formation of } \\
\text { strengthen and expand the boundaries of } \\
\text { competition (open for the free movement of } \\
\text { services and goods markets); the } \\
\text { implementation of the national transit } \\
\text { resources. }\end{array}$ & $\begin{array}{l}\text { The national carrier, "The railway of Kazakhstan" } \\
\text { profitable segments of repression. }\end{array}$ \\
\hline
\end{tabular}

The purpose of the railroad: the satisfaction of the passengers of the republic for the carriage of cargo, mail and baggage with care; to stabilize the development of the section via 
the passage to a new level; cost reduction in our transport from the Letter of producers, increasing the quality of transport services, increase their range; achieving security in rail services; sociality develop transit transport Kazakhstan; an increase in high-tech transports.

\section{Conclusion}

The results of the study allow us to draw the following conclusions: it must be remembered that the large volume of transport as the greater the problems. It should be careful vigilant in these issues and pay attention to any changes in their action. Because in our area a lot of natural resources, our country will develop.

In use, a change in the extraction of natural resources Railways has its own significance. Summing up the results of the article, which is one of the largest farms in the country as a whole, has the arteries of the economy, "The railway of Kazakhstan" NC "look forward to the future. He hope for a future independent state, overcome difficulties caused by our good will I am confident. Reviews of all to solve these problems in the financial sector of the Republic of Kazakhstan at the moment that there is a possibility to find ways to identify and resolve key issues must be noted.

\section{References}

1. Strategy of Industrial and Innovation Development of Kazakhstan for 2003-2015

2. Business site control and monitoring of financial market National Bank of Kazakhstan www.afn.kz

3. N.K.Kuchukova, Macroeconomic aspects of reforming the financial system over the years of independence of Kazakhstan: background, trends and prospects.

4. N. M. Alashbaieva. International Journal of Advanced Research, Volume 4, Issue 2, xxxxJournal homepage: http://www.journalijar.com International journal of advanced research,2320-5407, (2016)

5. N. M. Alashbaieva. International Business Management Scopus Pakistan. Number of issues per year: 6 ISSN:1993-5250 (Print) ISSN : XXXX-XXXX (Online). 0,129 STR Scopus(2016 Volume 10)

6. N. M. Alashbaieva. Asian Social Science, Scopus, SJR (SCImago Journal Rankings), (2013)

7. Faroukh Nourzad. Journal of economics and finance, 26, 139, 2012

8. Devereux M., Smith G. International Risk Sharing and Economic Growth // International economic Review. №35

9. Obstfeld M. Risk-Taking Global Devirsification and Growth // American economic Review. №84 8.http://adilet.zan.kz

10. Law of the Republic Kazahstan on December 8, 2001 № 266-II «On railway transport" (changes with amendments as of 09.29.2014)

11. Kaliev E.Zh. "Secular activities rail transport Kazakhstan". Almaty: RGP "The railway of Kazakhstan" NC

12. N. M. Alashbaieva Comparative analysis of innovation processes in the cis countries $\mathrm{L}$ Association1901 «SEPIKE»2014 Франция.

13. N. M. Alashbaieva Innovative content in the management of certain types of risks in the stock market IJAR ISSN: 2075-4124 (print), (online) -IndexCopernicus International(ICV: 6,74 2012) -Master Journal List (ISI - Thomson - Reuters, without impact faktor) 
14. Modern rail modern Europe // Directorate-General for Energy and Transport: European CommunitiesReproduction is authorised provided the source is acknowledged P.16, 2008 15. Keister A. L. Financial Markets, Money and Banking// Annual Review of Sociology, 2012. -Volume 32- P. $59-81$ 